\title{
TIEDEKUSTANTAJAT OTTAVAT VAUHTIA TEKOÄLYYN
}

\author{
Mitä tiedejulkaisemisen käytäntöjä tekoäly haastaa ja mitä \\ uusia mahdollisuuksia se avaa? Frankfurtin kirjamessut tarjo- \\ sivat kirjastoammattilaiselle kiinnostavan tilaisuuden tutustua \\ tekoälyvisioihin tiedekustantajien näkökulmasta.
}

Osallistuin Frankfurtin kirjamessuille lokakuun puolivälissä tarkoituksenani tutustua suomalaiseen kirjallisuusvientiin alan tärkeimmässä eurooppalaisessa tapahtumassa. Satuin eräänä messupäivänä kulkemaan tiedekustantajien hallissa juuri silloin, kun eräällä lavalla esiteltiin kustantajille tekoälysovellusten mahdollisuuksia ja haasteita. Kuuntelemaan jääminen kannatti, sillä nappasin kännykkääni monia uusia linkkivinkkejä ja kuulin kiinnostavia keskusteluja. Tässä artikkelissa raportoin kuulemaani ja näkemääni sekä taustoitan aihetta koskevilla lähteillä.
Tiedekustantajat tekoälytoiveikkaita

$\boldsymbol{T}$ ielä kymmenisen vuotta sitten digitaalinen teknologia herätti kustannusalalla pelkoa siitä, että painettu kirja häviää markkinoilta ja liiketoimintamallit täytyy tyystin uudistaa. Tänä päivänä näytetään olevan vastaavan murroksen äärellä, kun tekoälyksi kutsutut teknologiset ratkaisut ovat ilmestymässä julkaisemisenkin toimialalle. Johtuneeko aiemmista digitalisaatiokokemuksista, että huolestumisen sijaan nämä uudet teknologiat herättävätkin kustantajissa

\section{WHAT}

HAPPENS

WHEN

A

\section{MACHINE}

CURATES

LITERATURE

AND

ART? 


\section{8}

toiveikkuutta. Vasta julkaistun markkinakartoituksen mukaan monet kustantajat aikovat tulevan vuoden sisällä investoida tekoälysovelluksiin, elleivät ole sitä jo tehneet (AI in Academic Publishing Survey 2019).

Uudet teknologiat voivat näyttäytyä houkuttelevina myös siksi, että kustannusalan ympärillä on muuta kuohuntaa. Kaunokirjallisuuden kustantajat sopeutuvat viihdekuluttamisen uusiin muotoihin kasvattamalla tilausperustaisia e-kirja- ja äänikirjapalveluitaan (Albanese 20I9). Tällaiset viihdekanavapalvelut hyödyntävät suosittelualgoritmeja, jotka tarjoavat kullekin käyttäjälle juuri häntä houkuttelevaa sisältöä.

Tiedekustantamisen puolella liiketoiminnan perustuksia on järisyttänyt tiedeyhteisöissä voimistunut avoimen julkaisemisen liike, jonka tämän hetken vahvin vaikuttaja on eurooppalainen Plan S -aloite. Kustantajien täytyy nyt sopeutua nopeasti tieteen rahoittajilta tulleisiin vaatimuksiin ja samalla etsiä keinoja kilpailukykynsä säilyttämiseen. Kaikkeen, mikä mahdollistaisi tiedekustantamon olemassaolon Plan S:n voimaantulon jälkeen näytetään suhtautuvan suopeasti (vrt. mm. Albanese 2019, Sayer 2019).

Kustantajille olennaista uusien teknologisten innovaatioiden käyttöönotossa on oletettu hyöty. Yrityksellä täytyy olla kirkas kuva siitä, mitä investoinnilla saavutetaan, miten paljon se tuo säästöä ja miten uudet teknologiat istuvat perinteisiin toimituksen ja tuotannon prosesseihin (Paneelikeskustelu I 8.10.2019, AI in Academic Publishing Survey 2019).

\section{Tehokkuutta työprosesseihin}

7 ustannusalan kilpailu on kovaa ja siksi kilpailuetua etsitään kaikista mahdollisista tuotannon vaiheista. Työvoimavaltaisia prosesseja mallinnetaan ja opetetaan tietokoneille, toiveena poistaa toimitustyöstä turhat pullonkaulat ja inhimilliset virheet (Groth 2019). Kustantajat pitävät työajan säästöä tällä hetkellä tärkeimpänä tekoälysovellusten tarjoamana hyötynä (AI in Academic Publishing Survey 2019).

Lähetettyjen käsikirjoitusten hitaaksi koettuun käsittelyyn on lähdetty kehittämään työkaluja, joiden avulla julkaisija voi plagiaattitarkistuksen ohella tarkistaa käsikirjoituksen teknisen virheettömyyden, kielen ja tärkeimmät väittämät tai arvioida tutkimuksen uutuusarvoa. Useammatkin toimittajat tarjoavat tällaisia palveluja, joka hyödyntävät laajoja julkaistujen artikkelien tietokantoja, koneoppimista ja kieliteknologioita. Frankfurtissa esillä olivat ainakin Cenveo (https://www. cenveopublisherservices.com/editorial-journals), Impelsys (https://www. impelsys.com/publishing-solutions) ja Unsilo (https://unsilo.ai/unsilo-evaluate). Unsilon palvelussa on lisäksi käsikirjoituksen aihepiiriin sopivien vertaisarvioijien etsintä.

Frankfurtissa näin painettuna versiona Springerin tänä keväänä julkai- 
seman maailman ensimmäisen koneen koostaman tieteellisen julkaisun (lähdeluettelossa: Writer 20ı9). Tällä kokeilullaan Springer on kurottanut askeleen pidemmälle ja kokeillut, miten tämänhetkiseltä tekoälyltä sujuu tieteellisen tekstin tuottaminen.

Kustantajien keskusteluissa nousi esille toiveita myös tutkimustrendien automaattiseen tunnistamiseen, sillä trendikkäimmät aiheet lisäävät latauksia ja nostavat julkaisun vaikuttavuuskerrointa. Muiden muassa kirjastoillekin tuotteitaan markkinoivan Yewnon valikoimassa on palvelu, jolla voi tarkkailla, millaiset tutkimuksen teemat ovat nousussa tai laskussa (ks. https://www.yewno.com/unearth).

\section{Parempia palveluja ja käyttöliittymiä}

$\mathrm{T}$ utkimustiedon parempi saatavuus on keskeinen tavoite niin kirjastoille kuin kustantajillekin. Kun tieteellisten julkaisujen määrä kasvaa vuosittain muutamalla miljoonalla (Johnson ym. 20 I 8), ajankohtaisen tai vanhemmankin tutkimuksen löytäminen muuttuu perinteisin tiedonhakukeinoin sangen työlääksi. Uudenlaisia apuvälineitä siis tarvitaan.

Kuten kirjastot niin myös kustantajat pyrkivät edistämään aineistojen löydettävyyttä metadatan avulla, kontrolloiduilla ja linkitetyillä sanastoilla. Markkinaselvitykseen vastanneista kustantajista lähes puolet hyödynsivät tekoälyä automaattiseen tekstien analysointiin ja metadatan tuottamiseen (AI in Academic Publishing Survey 2019). Vaikka metadatatuotanto katsotaan edelleen kustannustalon sisäiseksi toiminnoksi, myös luotettavien toimittajien palveluita arvostetaan. Esimerkkinä Frankfurtissa mainittiin I970-luvulta saakka toiminut yhdysvaltalainen Access Innovations, joka lupaa mm. tuottaa joka organisaation tarpeisiin sopivan sanaston tai ontologian (ks. https://www.accessinn.com/services).

Algoritmiliiketoiminta näyttää kasvattavan osuuttaan myös tiedejulkaisemisen ympärillä. Markkinamenestystä haetaan panostamalla parempiin käyttöliittymiin ja hakutulosten visualisointeihin, kuten ovat tehneet Frankfurtin lavalla esimerkeiksi nostetut Yewno (https://www.yewno.com/discover) ja Semantic Scholar (https://www.semanticscholar.org) (Groth ym. 2019).

Lisääntyvästä ohjelmisto- ja palvelutarjonnasta huolimatta valtaosa kustantajista ymmärtää, että tekoälyn hyödyntäminen edellyttää myös oman organisaation osaamisen kehittämistä (AI in Academic Publishing Survey 20I9). Kustantajat kannustavat toisiaan investoimaan dataan ja sen älykkääseen käsittelyyn (Tan 2019). Kaiken tämän kuulemani ja lukemani perusteella meneillään näyttää olevan tiedekustantajien vauhdinotto tekoälyyn.

\section{Entä vaikutukset?}

Vierailu Frankfurtin kirjamessuille osoitti minulle sen, että kirjastojen on syytä seurata tiedekustantajien tekoälytoimia. Kuulemissani puheen-

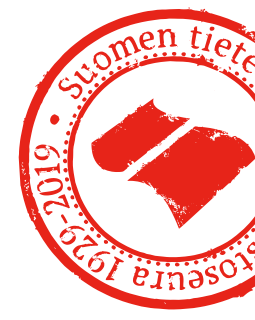


vuoroissa korostettiin, että kustantajat pitävät laatunäkökulmia erittäin tärkeinä (Groth ym. 20I9, Prabhu 2019, vrt. Shoenenberger 2019). Silti markkinaselvitys viittaa siihen, että harva kustantaja panostaa tällä hetkellä uusien sovellustensa mahdollisten vinoumien tarkastamiseen, saatikka ehkäisyyn (AI in Academic Publishing Survey 20 I9).

Matemaattisten mallien tuottama tieto on lähtökohtaisesti erilaista kuin ihmisen tuottama. Algoritmien tai datan aiheuttamat vinoumat voivat johtaa dramaattisesti virheellisiin päätelmiin tai vain huonoon lopputulokseen (ks. esim. Lee ym. 2019). Millaiseen suuntaan tiede mahtaa kääntyä, jos tai kun algoritmien annetaan valita tieteellisten artikkeleiden vertaisarvioijat tai arvioida käsikirjoitusten tutkimuksellinen uutuusarvo? Pitäisikö tiedeyhteisön jollain tavoin säädellä, miten paljon koneiden sallitaan avustaa tieteellisen tekstin tuottamista tai parantamista?

Tiedekustantajien siirtymistä käyttämään tekoälysovelluksia voidaan tarkastella myös tieteellisten kirjastojen edun näkökulmasta. Miten mahtavat tehokkaammat tuotantoprosessit näkyä lisenssisopimusten hintojen tai avoimen julkaisemisen maksujen perusteissa?

\section{Pysykäämme kirjastoissa kuulolla ja osallistukaamme keskusteluun}

Vastustanko sitä, että kustantajat ottavat tekoälyteknologiaa käyttöönsä? Päinvastoin. Toivon, että uudet väli- neet ylläpitävät julkaisualan monimuotoisuutta tarjoamalla pienemmille ja voittoa tuottamattomillekin kustantajillekin keinoja ylläpitää toimintaansa. Koska tiedekirjastot ja tiedekustantajat palvelevat samaa asiakaskuntaa, meidän tulisi käydä avointa keskustelua tekoälyteknologiaa hyödyntävien järjestelmien positiivisista ja negatiivisista vaikutuksista tieteen tekemisen käytäntöihin ja rakenteisiin.

Tieteellisen tiedon laadun takaaminen edellyttää jatkossa lisää läpinäkyvyyttä siihen, missä julkaisemisen prosesseissa algoritmeja hyödynnetään ja miten. Väitän, että tieteellisten kirjastojen tulisi olla mukana arvioimassa julkaisualalla käytettävien tietojärjestelmien vääristymävaikutuksia (bias impact statemets, vrt. Lee ym. 2019). Emme myöskään saisi unohtaa omien, algoritmejä hyödyntävien järjestelmiemme kriittistä arviointia ja läpinäkyvyyttä. (Toisin sanoen myös mainiossa Annif.org:issa tulisi olla kuvaus mahdollisista vääristymävaikutuksista, eikö vain!)

Tieteen tekemisen ja tiedeyhteisöjen edun mukaista olisi, että tiedekustantajat, ohjelmistotoimittajat ja tieteelliset kirjastot löytäisivät yhteisiä foorumeita, missä puntaroida uusien teknologioiden tarjoamia uhkia ja mahdollisuuksia. Mitä jos meitä kirjastolaisia olisi ensi vuonna Frankfurtissa muutama muukin kuuntelemassa - ja osallistumassa keskusteluun tiedekustantajien kanssa. 


\section{Koetut lähteet:}

Groth, Michael; Longo, Jim; Schoenenberger, Henning \& Thomas, Niels Peter. AI 2.o Machine-Generated Content, Intelligent Automation, and the Future of Academic Publishing. Paneelikeskustelu I 8.10.2019.Frankfurtin kirjamessut, Saksa.

Prabhu, John. Leveraging Technology to Create Intelligent Content. (Accessibility, Metadata, Indexing \& Abstracting). Esitys I 8.10.2019. Frankfurtin kirjamessut, Saksa.

\section{Julkaistut lähteet:}

AI in Academic Publishing Survey. 2019. Unisilo.ai. https://unsilo.ai/wp-content/

uploads/2019/ I I/unsilo-Survey-on-ai-in-Academic-Publishing-20 I9.pdf

(Luettu 23.11.2019)

Albanese, Andrew Richard 20 i9: What a Difference a Decade Makes. Frankfurt Book Fair - The Digital Spotlight, 3-4. Publishers Weekly.

Groth, Michael 20 I9: ai Goes from Disruptive to Imperative. Frankfurt Book Fair - The Digital Spotlight, Io-I 2. Publishers Weekly.

Johnson, Rob; Watkinson, Anthony \& Mabe, Michael 2018.

The STM Report, Fifth edition. An overview of scientific and scholarly publishing. stm: International Association of Scientific, Technical and Medical Publishers.

https://www.stm-assoc.org/20I8_IO_04_STM_Report_20 I 8.pdf (Luettu 20.I I.20I9)

Lee, Nicol Turner; Resnick, Paul \& Barton, Genie 2019. Algorithmic bias detection and mitigation: Best practices and policies to reduce consumer harms. Report. Brookings. https://www.brookings.edu/research/algorithmic-bias-detection-and-mitigation-bestpractices-and-policies-to-reduce-consumer-harms/ (Luettu 23.I I.2019)

SAYER, LIzZIE 2019: Scholarly publishers also need a more consistent approach. Interview with Steven Inchcoombe of Springer Nature on Plan S and Open Access. Blog post 20.3.2019. International Science Council. https://council.science/current/blog/ scholarly-publishers-also-need-a-more-consistent-approach-interview-with-steveninchcoombe-of-springer-nature-on-plan-s-and-open-access (Luettu 23.I I.2019)

Shoenenberger, Henning (2019). Preface. Teoksessa Beta Writer: Lithium-Ion Batteries. A Machine-Generated Summary of Current Research, ss. v-xxiii. Sringer Nature. https://doi.org/I0.1007/978-3-030-I6800-I

TAN, Teri (2019). Fast or Slow, Digitization Does Go on. Frankfurt Book Fair The Digital Spotlight, I6-22. Publishers Weekly.

Writer, Beta toim. (2019). Lithium-Ion Batteries. A Machine-Generated Summary of Current Research. Springer Nature. https://doi.org/I0.1007/978-3-030-I6800-I

\section{Tietoa kirjoittajasta}

\section{Heli Kautonen}

Suomalaisen Kirjallisuuden Seura

heli.kautonen@stks.fi

https://orcid.org/oooo-00o I-6652-I I 65 